\title{
Traditional versus modern apple cultivars - a comparison of juice composition
}

\author{
Justyna Dobrowolska-Iwanek ${ }^{1}$, Maciej Gąstot ${ }^{2 *}$, Agnieszka Adamska', \\ Mirostaw Krośniak ${ }^{1}$, Pawet Zagrodzki ${ }^{1,3}$
}

\author{
${ }^{1}$ Department of Food Chemistry and Nutrition \\ Jagiellonian University Medical College, Medyczna 9, 30-688 Kraków, Poland \\ 2 Department of Pomology and Apiculture \\ University of Agriculture in Krakow, 29 Listopada 54, 31-425 Kraków, Poland \\ ${ }^{3}$ Henryk Niewodniczański Institute of Nuclear Physics \\ Polish Academy of Sciences, Radzikowskiego 152, 31-342 Kraków, Poland
}

\begin{abstract}
Apples are rich in components that are important for human health, such as polyphenols, organic acids and microelements, but their chemical composition varies with different apple cultivars. We aimed to find out if there is any superiority in traditionally grown apple cultivars in terms of their fruits' bioactive components content. Juice from two traditionally grown apple cultivars, 'Mutsu' and 'Reinette Simirenko', was compared to eight popular apple cultivars, 'Jonagold', 'Jonagold Decosta', 'Jonica', 'Šampion', 'Gloster', 'Elise', 'Golden Delicious' and 'Rubin', and the results are presented. In the study we determined several major and minor nutrient elements, organic acids, phenolic content as well as the antioxidant activity of apple juice made from different cultivars, both modern and traditionally grown. Antioxidant activity determined as FRAP varied from 1.12 ('Elise') to 12.10 ('Jonagold') mmol Fe dm ${ }^{-3}$. The concentration of polyphenols fell between 0.16 ('Elise') and 1.30 ('Jonagold') $\mathrm{mg} \mathrm{ml}^{-1}$ gallic acid equivalent. Malic acid concentration was highest in 'Reinette Simirenko' and 'Mutsu' (6.58 and $5.84 \mathrm{~g} \mathrm{dm}^{-3}$, respectively) and lowest for 'Jonagold' $\left(3.73 \mathrm{~g} \mathrm{dm}^{-3}\right)$. The microelement concentrations for the apple cultivar juices were as follows: $8-24 \mathrm{mg} \mathrm{dm}^{-3}$ for Na, 567-1022 $\mathrm{mg} \mathrm{dm}{ }^{-3}$ for $\mathrm{K}, 26.9-59.4 \mathrm{mg} \mathrm{dm}^{-3}$ for $\mathrm{Mg}$ and $0.105-0.201 \mathrm{mg} \mathrm{dm}^{-3}$ for $\mathrm{Zn}$. Statistical analysis confirmed a highly positive correlation between total polyphenols and antioxidant activity $(r=0.98, p=0.001)$.

The study revealed that modern apples had the same or higher value of bioactive compounds in comparison to the older varieties. The highest pro-health activity among the investigated apple cultivars was found in the 'Jonagold' and 'Rubin' cultivars. Other studied cultivars - with the exception of the older ones, 'Reinette Simirenko' and 'Mutsu' - had much smaller pro-health activity. Therefore, 'Reinette Simirenko' and 'Mutsu' can be a worthwhile alternative for consumers in the future.
\end{abstract}

Key words: antioxidant activity, apple juice, nutrient elements, organic acids, polyphenol

\section{INTRODUCTION}

The popularity of apples is not only a result of their taste, but also of their high nutritional value and healthful properties. It is a well-known fact that apples are a rich source of polyphenols (Juranovic et al. 2011). What is more, the concentration of free phenolics in apples is the highest amongst all fruits (Sun et al. 2002) and for that reason these

\footnotetext{
*Corresponding author.

Tel.: +48 1266252 26; fax: +48 1266252 26;

e-mail: rogastol@cyfronet.pl (M. Gąstoł).
} 
compounds may be assimilated in higher amounts from apples. Phenolics, which are naturally existing antioxidants, demonstrate a variety of biological activities that may protect against the development of some chronic diseases, such as cardiovascular disease, obesity, diabetes, cancer and asthma; they may also have a beneficial influence on preventing premature ageing (Boyer and Liu 2004). Moreover, animal and in vitro studies have proved that apples may contribute to protecting macromolecules (mainly DNA and lipids) against oxidative damage induced by reactive oxygen species (Gerhauser 2008). Malic acid is also abundant in apples and apple juice. Malate plays an important role in generating the mitochondrial ATP while malic acid itself is one of the most effective compounds in decreasing the aluminium level in the brain (Abraharn and Flechas 1992). It is also an effective chelating agent, capable of binding to and inactivating some toxic metals (Domingo et al. 1988). In addition to different classes of phenolic compounds, organic acids and vitamins, apples contain some essential elements, such as $\mathrm{K}, \mathrm{Na}, \mathrm{Ca}, \mathrm{Mg}, \mathrm{Zn}$ and $\mathrm{Mn}$.

Apple trees are the most common fruit trees grown in Poland, and constitute $66.5 \%$ of the total area of orchards. In addition, with an annual production of around three million tons of apples, Poland is one of the largest exporters of these fruits to the European market (19.6\% of the total apple production in the European Union). Poland is also the third largest producer of apple concentrate in the world (according to FAO, EUROSTAT).

A number of significant changes took place in the Polish fruit tree market in the second half of the $20^{\text {th }}$ century in conjunction with modern fruit farming. Well known and widely spread apple cultivars in the interwar period, such as 'Oliwka Inflancka', 'Kronselska', 'Kosztela', 'Antonówka' and 'Złota Reneta', have been replaced by modern, annually yielding ones, such as 'Jonagold' and 'Idared' (Dziubiak 2005). However, these highly economical cultivars are often of lower nutritional quality (Drogoudi et al. 2008, Iacopini et al. 2010). Some studies have linked lower nutritional value with an intensification of fruit production in the last decades (Mayer 1997).

Therefore, the objective of this study was to prove the hypothesis that traditionally grown apple cultivars are superior in terms of bioactive components in the fruit.

\section{MATERIAL AND METHODS}

\section{Apple cultivars, harvest and storage condition}

Fruit samples of 'Jonagold', 'Jonagold Decosta', 'Jonica', 'Šampion', 'Gloster', 'Elise', 'Golden Delicious', 'Rubin', 'Reinette Simirenko' and 'Mutsu' apple cultivars were taken from an orchard located at the Experimental Station of the Agricultural University in Garlica Murowana, near Krakow. Fruits were harvested from 16-year old apple trees grafted on M.26 rootstock. The soil of the plot where the fruit trees were planted was in the valuation class II $b$, which is classified as a brown soil type developed from loess and represents a type described as a silt loam. The data on some soil properties are given in Table 1. In the orchard, the soil cultivation system was an herbicidal fallow in rows and grass in the inter-rows. Trees were spaced at $4.0 \times 1.5 \mathrm{~m}$. The crowns of trees were trimmed in a spindle-shaped form. The trees were grown according to the recommendations for commercial orchards. The Streif index (SI = Firmness/(Refraction $\times$ Starch stage)) was used to determine the harvest time.

Two groups of cultivars were taken for the study: the traditional ('old'), which were bred in the $19^{\text {th }}$ / beginning of the $20^{\text {th }}$ century ('Reinette Simirenko', 'Golden Delicious' and 'Mutsu') and modern ones. Among them, 'Jonagold' apples are crisp and juicy with aromatic honey-like sweetness and moderate acidity. The fruit flesh has a low tendency to browning. Fruits have good storage properties, up to 10 months in controlled atmosphere storage. 'Jonagold' apples are excellent not only for eating when fresh, but also as an ingredient of salads and baked goods; they also serve as an excellent source of apple juice. So far, over 70 sports (strains) of 'Jonagold' have been discovered (Schechter and

Table 1. Mean values of $\mathrm{pH}_{\mathrm{H}_{2} \mathrm{O}}$, soil organic matter, available macroelements ( $\mathrm{mg} \mathrm{dm}{ }^{-3}, 0.03 \mathrm{M} \mathrm{CH}_{3} \mathrm{COOH}$ extraction)

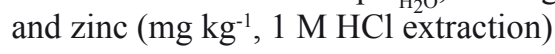

\begin{tabular}{lcccccccc}
\hline Soil layer & $\mathrm{pH}_{\mathrm{H} 2 \mathrm{O}}$ & $\begin{array}{c}\mathrm{SOM} \\
(\%)\end{array}$ & $\begin{array}{c}\mathrm{Ca} \\
\left(\mathrm{mg} \mathrm{dm}^{-3}\right)\end{array}$ & $\begin{array}{c}\mathrm{K} \\
\left(\mathrm{mg} \mathrm{dm}^{-3}\right)\end{array}$ & $\begin{array}{c}\mathrm{Mg} \\
\left(\mathrm{mg} \mathrm{dm}^{-3}\right)\end{array}$ & $\begin{array}{c}\mathrm{P} \\
\left(\mathrm{mg} \mathrm{dm}^{-3}\right)\end{array}$ & $\begin{array}{c}\mathrm{S} \\
\left(\mathrm{mg} \mathrm{dm}^{-3}\right)\end{array}$ & $\begin{array}{c}\mathrm{Zn} \\
\left(\mathrm{mg} \mathrm{kg}^{-1}\right)\end{array}$ \\
\hline $0-20$ & 5.22 & 1.43 & 558 & 123.0 & 90.0 & 21.70 & 6.20 & 12.8 \\
$20-40$ & 6.19 & - & 489 & 80.1 & 66.6 & 5.40 & 3.80 & 12.1 \\
\hline
\end{tabular}


Proctor 1989). The Czech apple cultivar 'Rubin' was selected as a seedling of the 'Lord Lambourne' $x$ 'Golden Delicious' crossing. It has gained some interest due to its exceptionally high dessert quality. Among the new cultivars, 'Rubin' apples are recognized to be the tastiest (Paprstein et al. 2006). Apart from their excellent taste, these fruits are large and covered with a beautiful carmine colour (Kruczyńska 2002). 'Reinette Simirenko' (='Wood's Greening') originated from the garden of Ukrainian pomologist Leo Simirenko in 1895. The peel is light green, similar to 'Granny Smith'. Its flesh is greenish, white or nearly white, finegrained, slightly crisp and tender. It is delicately tart and well balanced. Not only does it have a pleasant texture, but also an outstandingly citruslike flavour (Bordeianu et al. 1964). 'Šampion' has been one of the most important cultivars in Poland for many years (Du Bruille and Barritt 2004). It comprises an excellent taste (hybrid of 'Golden Delicious' × 'Cox Orange Pippin'), high productivity and easy cultivation (Mika 2002, Żurawicz 2003). 'Mutsu' (='Crispin') was bred in Aomori, Japan in 1930 ('Golden Delicious' $\times$ 'Indo' hybrid). It reveals a sweet honeyed yet a very refreshing flavour. The flesh is very juicy and crisp. The fruits are very large (triploid) while their skin colour is a yellowish green with an orange blush. It is a versatile cultivar (used for desserts, juices and baking) (Rejman 1994). 'Gloster' fruits are moderately large, roundish to conically elongated (resembling the 'Red Delicious' variety), with a yellow-greenish basic colour, covered with a red to dark-red colour on almost the whole fruit. The flesh is pale cream-colored, crackling and sweet, with a melon-like aroma (Petzold 1990). 'Elise' apples have an excellent taste and they can be stored for long periods of time as they have an exceptionally long shelf life (7-10 days). They are large, mainly cone-shaped fruits with a practically even dark-red blush on a yellow-green background. The combination of an excellent taste, long storage ability and shelf life makes 'Elise' a unique cultivar. Moreover, 'Elise' apples can be safely consumed by most people with a mild apple allergy (Kruczyńska 2002, Vlieg-Boerstra et al. 2011).

\section{Sample preparation}

Two kilograms of apples from each cultivar were chosen at random. After being washed in water, the apple stalks were removed from the samples. Next, two separate quarters from each apple were cut out - one from the primary colour quarter, the other one from the red blush quarter. Then the apple pulp was put into the juice extractor. The obtained juice was stored at $-20^{\circ} \mathrm{C}$ until it was used for the analysis.

\section{Instrumentation}

FRAP (Ferric Reducing Antioxidant Power ) assay was conducted as described by Paśko et al. (2009). The final results were given as $\mathrm{mmol} \mathrm{Fe}{ }^{2+} \mathrm{dm}^{-3}$.

Total phenolic compounds (TPC) were determined using the Follin-Ciocalteu reagent. The analytical procedure was performed as described earlier (Paśko et al. 2009) with some modifications. The absorbance was measured at $725 \mathrm{~nm}$ using a UV/VIS laboratory spectrophotometer (Synergy 2, Bio Tek Instruments). Final results were expressed as $\mathrm{mg} \mathrm{ml}^{-1}$ gallic acid equivalents.

Malic acid was determined using the Electrophoretic Analyser EA 202M (Villa Labeco, Spisska Nova Ves, Slovakia) with conductivity detection. The leading electrolyte was hydrochloric acid $(10 \mathrm{mM})$ including $0.2 \%$ methylhydroxyethylcellulose (M-HEC) adjusted with $\beta$-alanine to $\mathrm{pH}$ 3.5. The terminating electrolyte contained $5 \mathrm{mM}$ caproic acid and $5 \mathrm{mM}$ histidine. The system was equipped with a sample valve of $30 \mu \mathrm{m}$ fixed volume and two capillaries: the preseparation capillary $(90 \mathrm{~mm} \times 0.9 \mathrm{~mm} \mathrm{I.D}$.) and the analytical capillary $(160 \mathrm{~mm} \times 0.3 \mathrm{~mm}$ I.D. $)$. Samples were diluted with distilled water in order to obtain a malic acid concentration range between 10 and $80 \mathrm{mg} \mathrm{dm}^{-3}$.

We also assessed elements important for human daily intake, namely sodium, potassium, magnesium and zinc. The determination was performed using the Atomic Absorption Spectrometer (Perkin Elmer 5100ZL). Final results were expressed as $\mathrm{mg} \mathrm{dm}^{-3}$. All analyses were repeated in triplicate.

\section{Statistical Analysis}

Values are given as means \pm SD of three measurement. Data were tested by one-way ANOVA using Statistica 5.1 (StatSoft Inc., USA) followed by the Tukey post hoc test. Pearson's correlation was used to find a correlation between the parameters. The significance level was set at $\mathrm{p}<0.05$.

Ward's minimum variance method was used in order to find the clusters consisting of either similar objects or parameters, with either Chebychev or Euclidean distances used as dissimilarity indices, respectively. Autoscaling was employed as a preprocessing method in order to equally weight all the original parameters for the cluster analysis. 


\section{RESULTS AND DISCUSSION}

The antioxidant activity of the methanolic extract of different apple juices was estimated on the basis of the ability to reduce ferric (the tripyridyltriazine (FeIII-TPTZ) complex to the ferrous (Fe II) form). The results are shown in Figure 1. Different apple cultivar juices were characterised by various values of the antioxidant potential. FRAP values in the extract varied between 1.12-12.10 mM Fe $\mathrm{dm}^{-3}$. 'Elise' apple juice was distinguished by the lowest antioxidant potential, and 'Jonagold' apple juice by the highest antioxidant potential.
The results of the total phenolic content in the extracts are shown in Figure 2. A wide variation of TPC in juices obtained from different cultivars of apples was observed. The values varied between $0.16-1.30 \mathrm{mg} \mathrm{ml}^{-1}$ gallic acid equivalent. The highest content of the total phenolic compounds was determined in 'Jonagold' juice, whereas the lowest was found for 'Elise' juice. Moreover, apples with a higher phenolic concentration also tended to have a higher antioxidant activity $(\mathrm{r}=0.98, \mathrm{p}=0.0001)$.

The concentration of malic acid was determined with the use of the isotachophoresis method. Acid concentration in apple juices ranged between 3.73 and $6.58 \mathrm{~g} \mathrm{dm}^{-3}$ (Fig. 3); the highest concentration

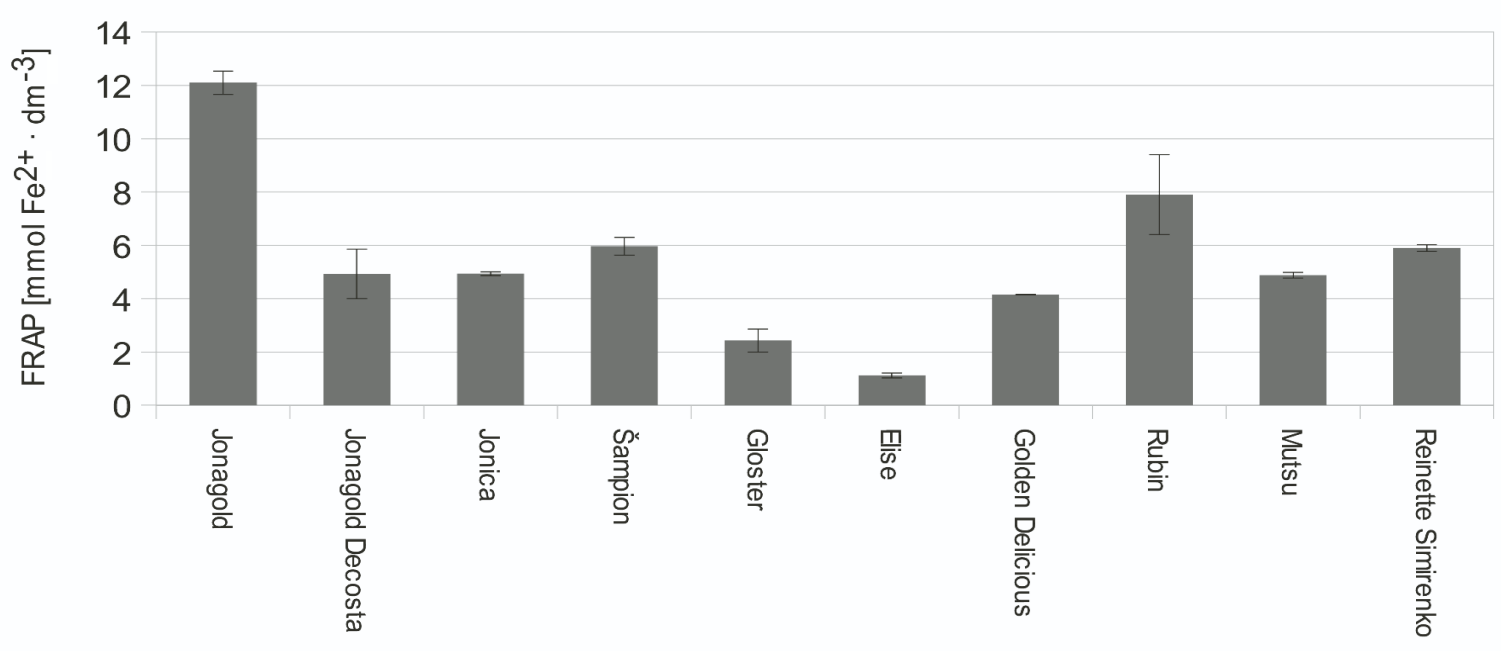

Apple cultivars

Figure 1. FRAP for various apple juices

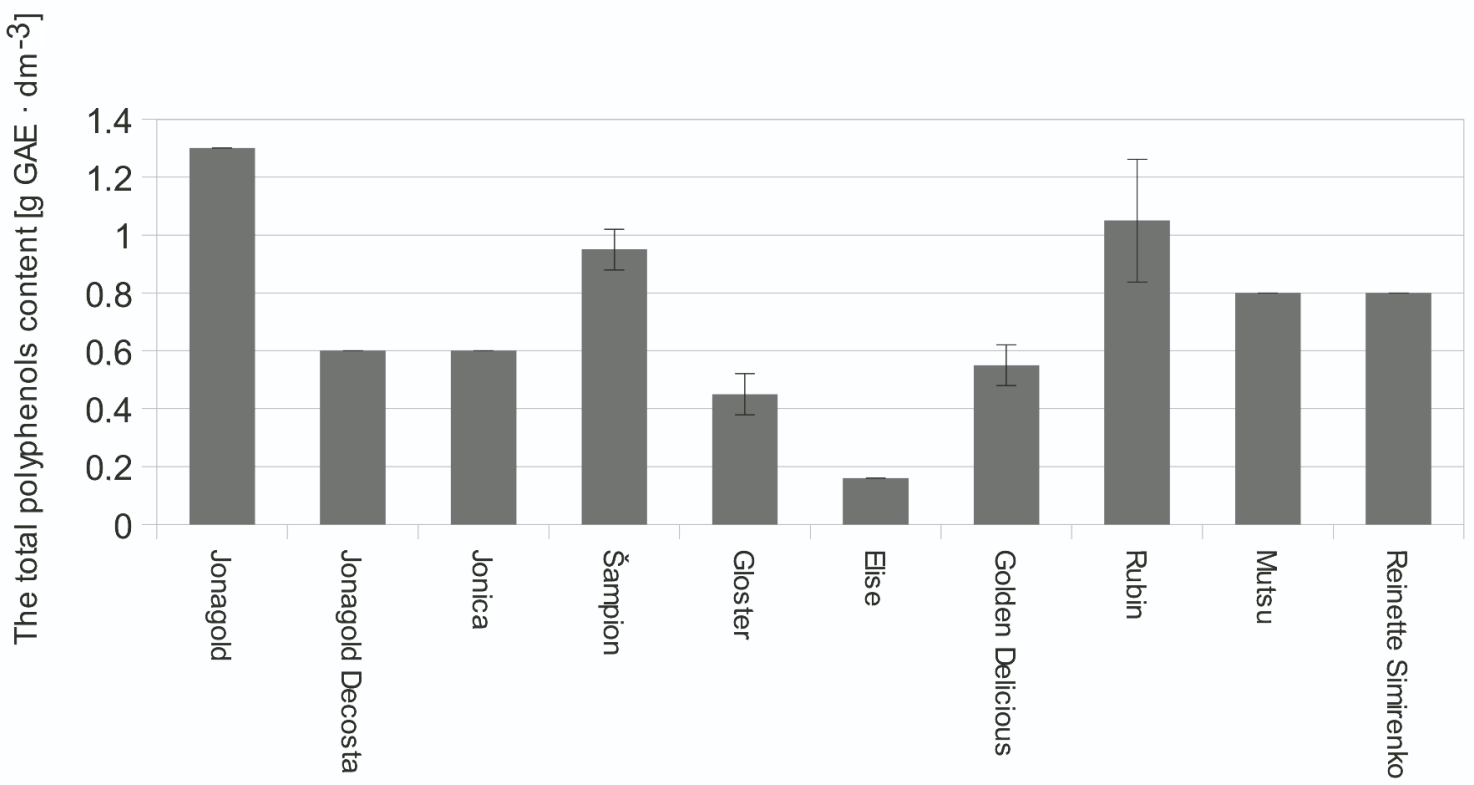

Figure 2. Concentration of polyphenols in apple juices 


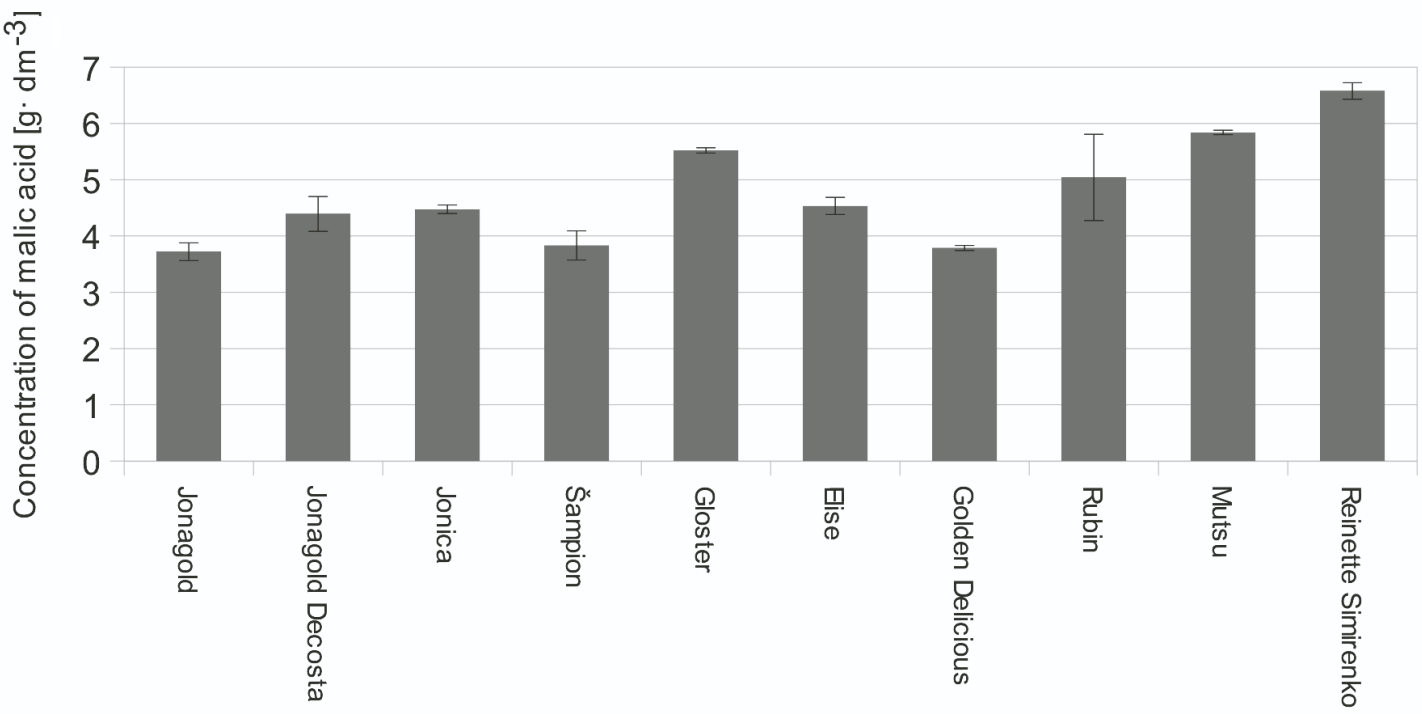

Figure 3. Concentration of malic acid in apple juices

of malic acid was found in 'Reinette Simirenko' while the lowest was in 'Jonagold' juice.

The samples of apple juice were also analysed in order to determine the concentration of sodium, potassium, magnesium and zinc. The following concentration ranges were obtained for the determined elements: $8-24 \mathrm{mg} \mathrm{dm}^{-3} \mathrm{Na}, 567-1022$ $\mathrm{mg} \mathrm{dm}{ }^{-3} \mathrm{~K}, 26.9-59.4 \mathrm{mg} \mathrm{dm}{ }^{-3} \mathrm{Mg}$ and 0.105$0.201 \mathrm{mg} \mathrm{dm}^{-3} \mathrm{Zn}$. The results are shown in Figure 4A-D. Statistical analysis has revealed a highly positive correlation between sodium and malic acid concentrations $(r=0.78, p=0.0001)$. The rest of the correlations were not statistically significant.

The results of the cluster analysis are shown in Figure 5. On the basis of the presented dendrogram, as well as the values of variables for the respective apple cultivars, one can say that cultivars creating one-element clusters ('Rubin' and 'Jonagold') differed from other cultivars (in clusters 2-4) by a higher FRAP value, and an augmented concentration of polyphenols and zinc. These two cultivars differ from each other as far as the

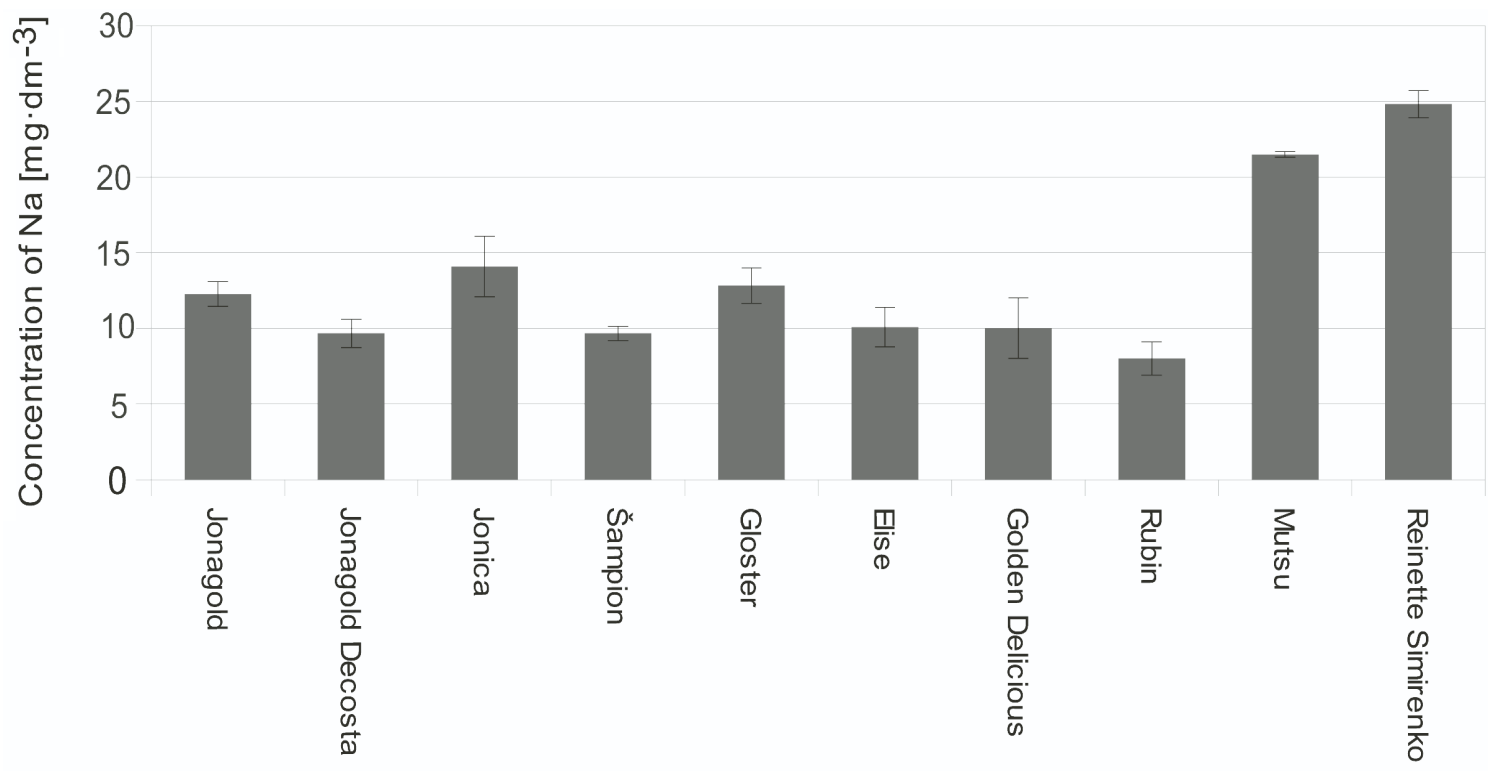

Apple cultivars

Figure 4A. Concentration of $\mathrm{Na}$ in apple juices 


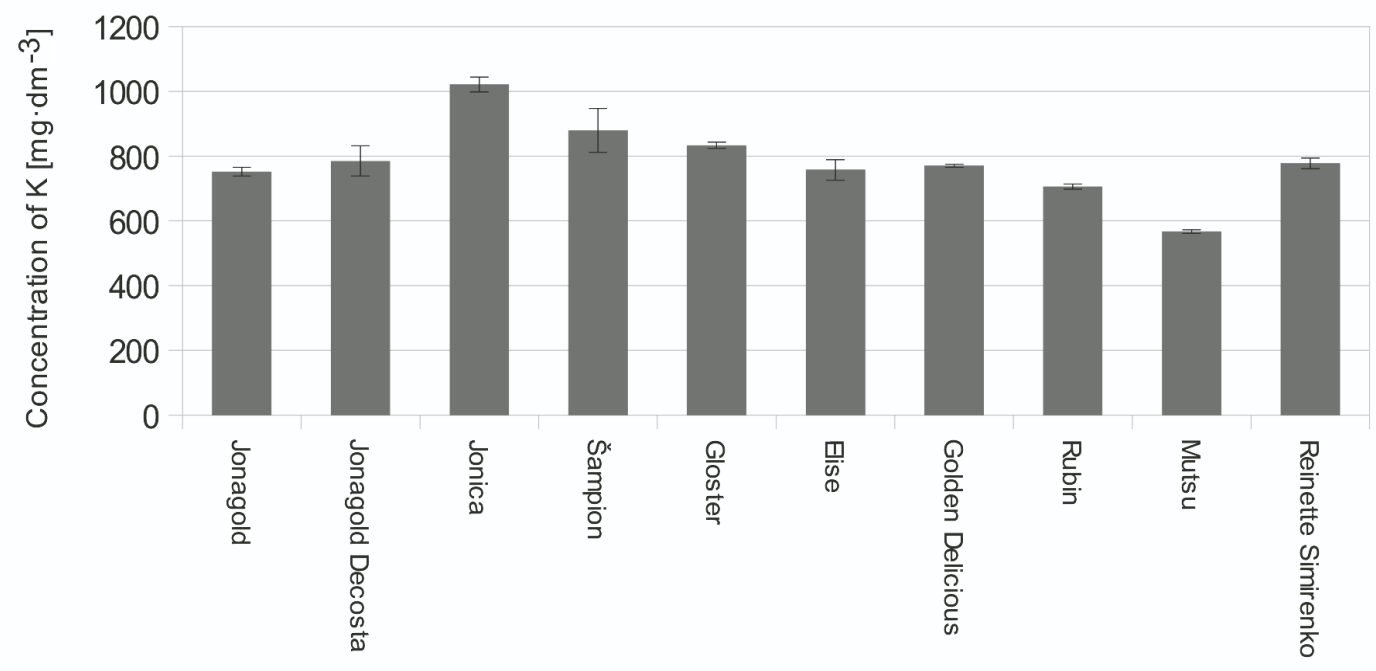

Apple cultivars

Figure 4B. Concentration of $\mathrm{K}$ in apple juices

concentration of magnesium is concerned, which is very high in the 'Rubin' cultivar and very low in 'Jonagold' (the lowest amongst all of the examined apple cultivars). Moreover, 'Jonagold' differed from cluster 4 (which is formed by 'Mutsu' and 'Reinette Simirenko') as far as malic and sodium concentration is concerned. Both parameters showed much higher concentrations in cluster 4 . The potassium concentration did not affect the results of the cluster analysis. Similarities between variables characterising the examined juices are shown in the next dendrogram (Fig. 6).

FRAP and polyphenol concentrations were in the same cluster, which indicates a high correlation between these two variables. Polyphenols are one of the main antioxidants in apple juice and that is why their concentration in juice affects the antioxidant power. A pair of two other parameters (i.e. sodium and malic acid) was found within another cluster, which points to a formation of organic salts.

The cluster analysis confirmed the results obtained by the Pearson correlation test. Almost a full correlation between the antioxidant activity and the total polyphenol concentration was found, as well as a very strong correlation between sodium and the malic acid concentration.

New apple cultivars frequently replace the old ones. They should have desirable properties such

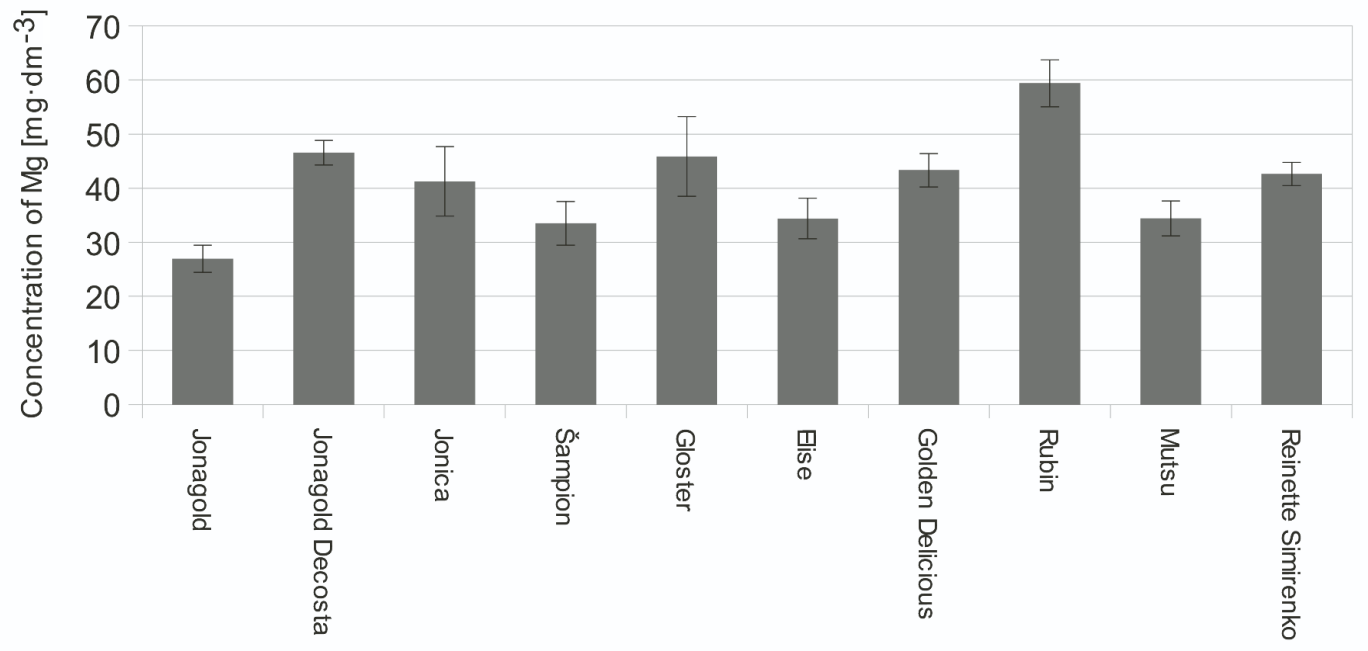

Apple cultivars

Figure 4C. Concentration of $\mathrm{Mg}$ in apple juices 


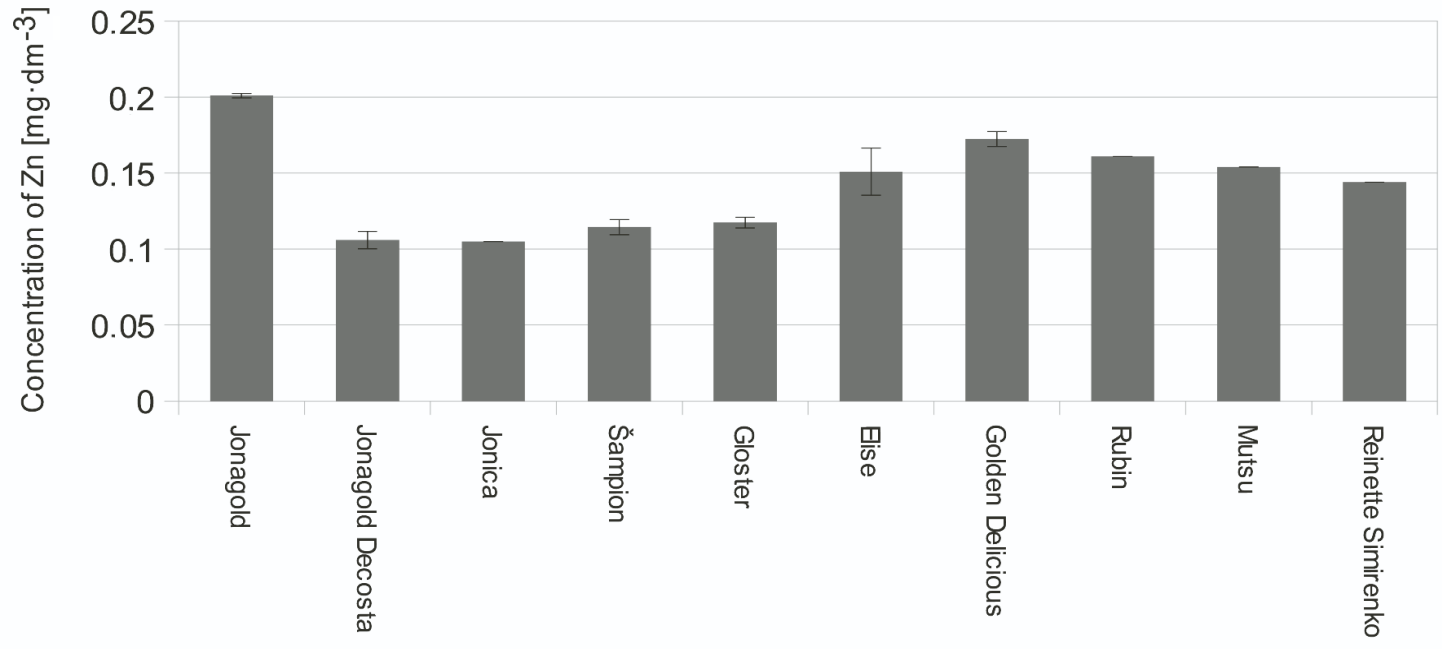

Apple cultivars

Figure 4D. Concentration of $\mathrm{Zn}$ in apple juices

as: pest, fungi and abiotic stress resistance, easy orchard management, as well as good fruit storage properties. Moreover, fruits with an excellent appearance (blush), texture, flavour (sweetness and acidity), and those with various possible applications (fresh snacks/industrial applications) are the most valuable. However, when focusing only on these features, one can easily overlook the properties that are important for human health.

Although the cultivation of some of the more popular apple cultivars is the optimal use from the production point of view, this may impoverish the richness of taste and the possibility of using such fruits for other nutritional purposes. Frequently, less-known apple cultivars have better properties in comparison to the popular ones (Duda-Chodak et al. 2010). All of the trees that were analysed in this study were grown in the same pomological orchard and consequently, cultivated in the same soil and climate conditions, and using the same method of fertilization in order to eliminate the possible influence exerted by these factors. Although

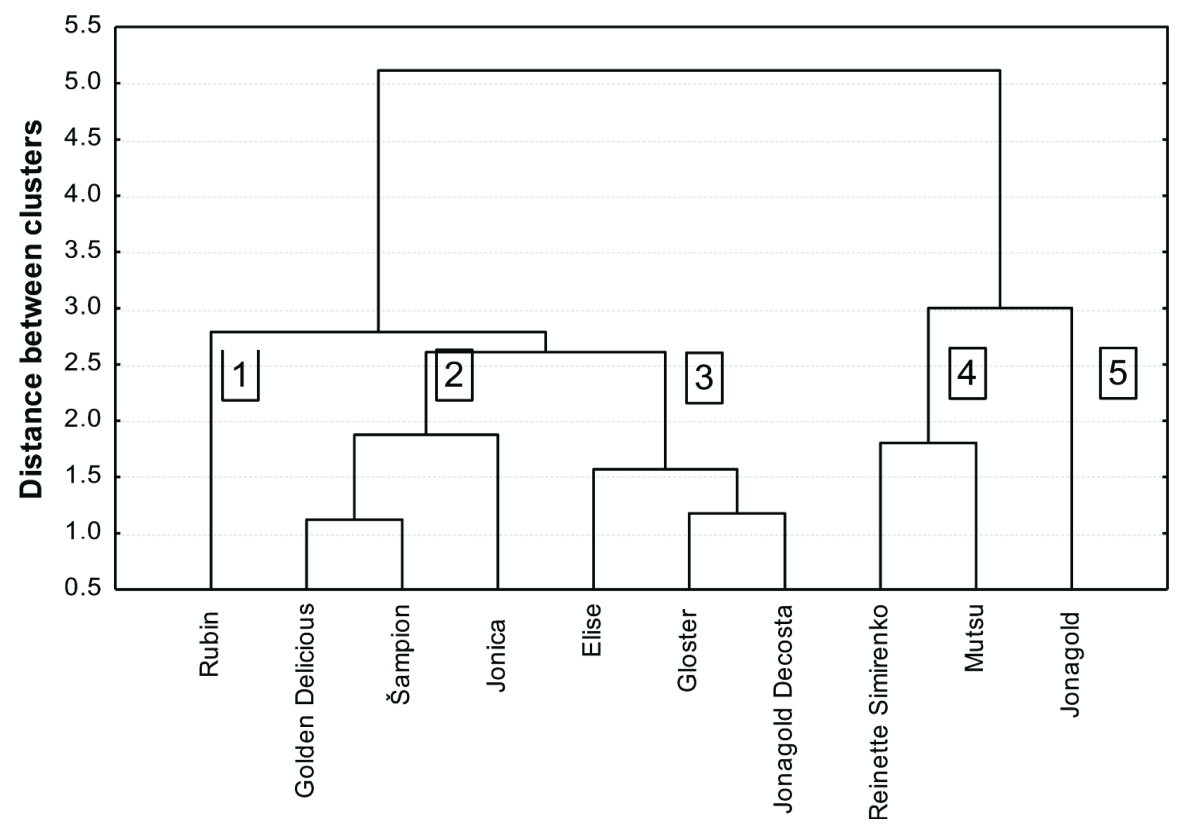

Figure 5. Branching-tree diagram for different apple species (the similarities between clusters were evaluated using Ward's method and Chebychev distance) 


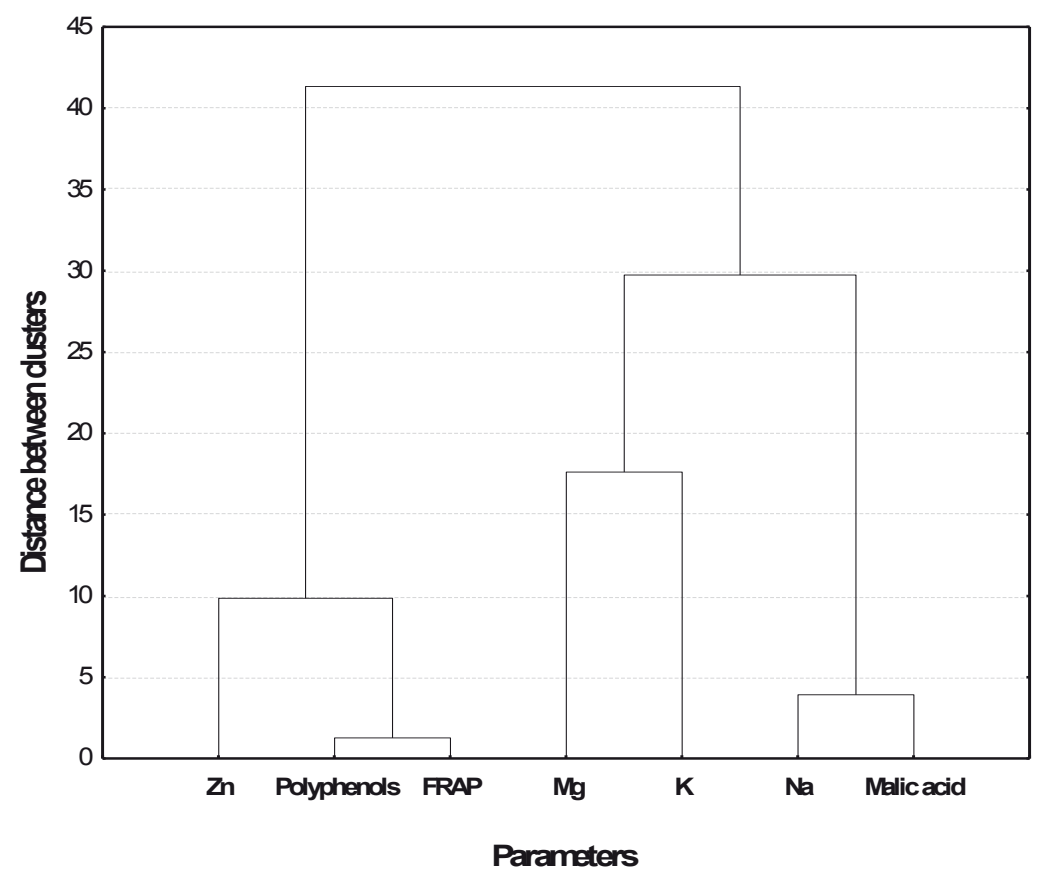

Figure 6. Branching-tree diagram for different parameters (the similarities between clusters were evaluated using Ward's method and Euclidean distance)

the analysis of the investigated apple cultivars confirmed some differences in their chemical content, there were not any evident differences between the analysed groups of old and new cultivars. The results of other researchers confirm the high antioxidant properties of the 'Jonagold' and 'Rubin' cultivars (Lachman et al. 2006). The other cultivars that are examined here have not been frequently studied elsewhere. This study for the first time provides relevant data for 'Reinette Simirenko' and 'Mutsu' in Polish conditions. Both these cultivars present similar antioxidant activity, as was revealed by cluster analysis. The content of active substances in these apples was lower when compared to 'Jonagold' and 'Rubin', but higher in comparison with the other investigated cultivars. 'Reinete Simirenko' is an interesting alternative for 'Granny Smith', which is not produced in Poland, and the price of this cultivar is higher than for other cultivars typical in Poland. The green colour of this apple peel is unique in comparison to other cultivars. The possibilities of using 'Reinnete Simirienko' as a replacement for 'Granny Smith' could create new opportunities for Polish producers. Moreover, 'Reinnete Simirienko' has a higher antioxidant activity. 'Mutsu' is another lesser-known cultivar in Poland that has interesting taste parameters. Not only does it have large fruits, but it is also very juicy and crisp and contains a creamy moderately sweet white flesh, which all in all creates a versatile cultivar for desserts, juices and for baking purposes. The 'Reinnete Simirienko' and 'Mutsu' cultivars showed the highest malic acid concentration in comparison to the other investigated cultivars. However, further study is necessary for a better understanding of how Polish cultivation conditions can influence the biochemical parameters of these two cultivars. On the other hand, the 'Gloster' and 'Elise' cultivars had the smallest concentration of active antioxidant substances in comparison to the other cultivars. The above observations are similar to those of Lachman and al. (2006) and Krośniak et al. (2009).

The macroelement analysis $(\mathrm{Na}, \mathrm{K}, \mathrm{Mg}$ and $\mathrm{Zn}$ ) presented in this study confirmed the results obtained by Juranović et al. (2011), and it did not prove any significant differences between the investigated cultivars.

\section{CONCLUSIONS}

1. The study did not confirm the superiority of older, traditional apples in term of their antioxidant status and nutritional value.

2. The highest pro-health activity amongst all of the investigated apple cultivars was found in the 'Jonagold' and 'Rubin' cultivars. Other studied cultivars - with the notable exception of 'Reinette Simirenko' and 'Mutsu' - are very 
popular in Europe, but show a much lower prohealth activity.

3. Lesser-known 'Reinette Simirenko' and 'Mutsu' (both green peeled cultivars) can be a worthwhile alternative in the future for consumers. Not only do they possess an interesting taste but also relatively rich pro-health properties for humans.

4. Element analysis ( $\mathrm{Na}, \mathrm{K}, \mathrm{Mg}$ and $\mathrm{Zn}$ ) did not prove any significant differences between the investigated cultivars. The experiment revealed a very strong correlation between sodium and malic acid concentration in the analysed apple juices.

\section{REFERENCES}

Abraharn G.E., Flechas J.D., 1992. Management of pibromyalgie: rationale for the use of magnesium and malic acid. J. Nutr. Med. 3: 49-59.

Bordeianu T., 1964. Pomologia. II Marul. Editura Acadeniei Republicii Populare Romina, Bukaresti: 589-593.

Boyer J., Liu R.H., 2004. Apple phytochemicals and their health benefits. Nutr. J. 3(5): 1-15.

Domingo J.L., Gómez M., Llobet J.M., Corbella J., 1988. Comparative effects of several chelating agents on the toxicity, distribution and excretion of aluminium. Hum. Exp. Toxicol. 7(3): 259-262.

Drogoudi P. D., Michailidisb Z., Pantelidisa G., 2008. Peel and flesh antioxidant content and harvest quality characteristics of seven apple cultivars. Sci. Hort. 115(2): 149-153.

Dziubiak M., 2005. Moda na stare odmiany jabłoni, Szkółkarstwo 1: 58-60.

Duda-Chodak A., Tarko T., Satora P., Sroka P., TuszyŃSKi T., 2010. The profile of polyphenols and antioxidant properties of selected apple cultivars grown in Poland. J. Fruit Ornament. Plant Res. 18(2): 39-50.

Du Bruille J., Barritt B.H., 2004. Global Apple Study - A Comparison of Production Practices and Costs of Production in Leading Apple Producing Countries. INTERPOMA: 5-16.

Dziubiak M., 2005. Moda na stare odmiany jabłoni, Szkółkarstwo 1: 58-60.

FAO, http://faostat.fao.org

EUROSTAT, http://epp.eurostat.ec.europa.eu

Gerhauser C., 2008. Cancer chemopreventive potential of apples, apple juice and apple components. Planta Med. 74: 1608-1624.

Iacopini P., Camangi F., Stefani A., Sebastiani L., 2010. Antiradical potential of ancient Italian apple varieties of Malus $\times$ domestica Borkh. In a peroxynitriteinduced oxidative process. J. Food Comp. Anal. 23: 518-524.

Juranovic C.I., Zeiner M., Kröppl M., Stingeder G., 2011. Comparison of sample preparation methods fort the ICP-AES determination of major and minor elements in clarified apple juices. Microchem. J. 99: 364-369.

KRUCZYŃSKA D., 2002. Jabłonie - nowe odmiany, Hortpress, Warszawa.

Krośniak M., Piotrowska A., BŁaszczyk J., 2009. Potencjał antyoksydacyjny oraz kwasowość w zależności od odmiany i zastosowania podkładki w jabłkach z okolic Krakowa. Bromatol. Chem. Toksyk. XLII(3): 904-909.

Lachman J., Š́llc M., Sus J., Pavlíková O., 2006. Polyphenol content and antiradical activity in different apple varieties. Hort. Sci. (Prague) 33(3): 95-102.

MAYER A.M., 1997. Historical changes in the mineral content of fruits and vegetables. Brit. Food J. 99(6): 207-221.

Mika A., 2002. Jabłoń. Multico Oficyna Wydawnicza, Warszawa.

Paprstein F., Blazek J., Michalek S., 2006. Effect of climatic conditions on fruit quality of apple cultivars assessed by public sensory evaluations in the Czech and Slovak Republics 1999-2004. J. Fruit Ornament. Plant Res. 14: 219-227.

Petzold H., 1990. Apfelsorten. Neumann Verlag, Radebeul: 67, 251.

Paśko P., Bartoń H., Zagrodzki P., Groinstein S., FoŁta M., Zachwieja Z., 2009. Antocyanins, total polyphenols and antioxidant avtivity in amaranth and quinoa seeds and sprouts during their growth. Food Chem. 115: 994-998.

Rejman A., 1994. Pomologia. Odmianoznawstwo roślin sadowniczych. PWRiL, Warszawa

Schechter I., Proctor J.T.A., 1989. 'Jonagold': An apple for 21 st century. Fruit Varieties J. 43: 4-6.

Sun J., Chu Y., Wu X., Liu R.H., 2002. Antioxidant and antiproliferative activities of common fruits. J. Agr. Food Chem. 50: 7449-7454.

Vlieg-Boerstra B.J., Van de Weg W.E., Van der Heide S., Kerkhof M., Arens P., Heijerman-Peppelman G., Dubois A.E., 2011. Identification of low allergenic apple cultivars using skin prick tests and oral food challenges. Allergy 66: 491-498.

Żurawicz E., 2003. Pomologia. Odmianoznawstwo roślin sadowniczych - aneks. PWRiL, Warszawa.

Received August 13, 2014; accepted February 9, 2015 